\title{
Photoresponsiveness affects life history traits but not oxidative status in a seasonal rodent
}

\author{
Anna S. Przybylska ${ }^{1 *}$ D, Michał S. Wojciechowski ${ }^{1}$ and Małgorzata Jefimow²
}

\begin{abstract}
Background: Shortening photoperiod triggers seasonal adjustments like cessation of reproduction, molting and heterothermy. However there is a considerable among-individual variation in photoresponsiveness within one population. Although seasonal adjustments are considered beneficial to winter survival, and natural selection should favor the individuals responding to changes in photoperiod (responders), the phenotype non-responding to changes in day length is maintained in population. Assuming the same resource availability for both phenotypes which differ in strategy of winter survival, we hypothesized that they should differ in life history traits. To test this we compared reproductive traits of two extreme phenotypes of Siberian hamster Phodopus sungorus - responding and nonresponding to seasonal changes in photoperiod. We bred individuals of the same phenotype and measured time to first parturition, time interval between litters, offspring body mass 3, 10 and 18 days after birth and their growth rate. We also analyzed nest-building behavior. Additionally, we estimated the correlation between reproduction, and basal metabolic rate (BMR) and oxidative status in both phenotypes to infer about the effect of reproductive output on future investments in somatic maintenance.

Results: Prior to reproduction responding individuals were smaller than non-responding ones, but this difference disappeared after reproduction. Responding pairs commenced breeding later than non-responding ones but there was no difference in time interval between consecutive litters. Responders delivered smaller offspring than non-responders and more out of responding individuals built the nest during winter than non-responding ones. Reproduction did not affect future investments in somatic maintenance. Phenotypes did not differ in BMR and oxidative status after reproduction. However, concentration of reactive oxygen metabolites (ROM) was highest in responding males, and biological antioxidant potential (BAP) was higher in males of both phenotypes than in females.

Conclusions: Delayed breeding in responding Siberian hamsters and high ROM concentration in male responders support our hypothesis that differences in adjustment to winter result in different life history characteristics which may explain coexistence of both phenotypes in a population. We propose that polymorphism in photoresponsiveness may be beneficial in stochastic environment, where environmental conditions differ between winters. We suggest that nonresponding phenotype may be particularly beneficial during mild winter, whereas responders would be favored under harsh conditions. Therefore, none of the phenotypes is impaired when compared to the other.
\end{abstract}

Keywords: Photoresponsiveness, Polymorphism, Reproduction, Life history traits, Basal metabolic rate, Oxidative stress

\footnotetext{
* Correspondence: annaprzybylska2808@gmail.com

'Department of Vertebrate Zoology, Nicolaus Copernicus University, ul.

Lwowska 1, 87-100 Toruń, Poland

Full list of author information is available at the end of the article
}

(c) The Author(s). 2019 Open Access This article is distributed under the terms of the Creative Commons Attribution 4.0 International License (http://creativecommons.org/licenses/by/4.0/), which permits unrestricted use, distribution, and reproduction in any medium, provided you give appropriate credit to the original author(s) and the source, provide a link to the Creative Commons license, and indicate if changes were made. The Creative Commons Public Domain Dedication waiver (http://creativecommons.org/publicdomain/zero/1.0/) applies to the data made available in this article, unless otherwise stated. 


\section{Background}

For small Temperate-Zone endothermic animals winter is one of the most energy demanding periods of the year. Low ambient temperature increases energy requirements, whereas food availability is greatly reduced $[1,2]$. To survive animals must adjust their physiology and behavior to prevailing environmental conditions. In small mammals these adjustments include gonadal regression and cessation of reproduction, decrease of body mass $\left(m_{\mathrm{b}}\right)$, and molt to a winter coat, all to ensure better thermal insulation and lower energy expenditure. Moreover, heterothermic species use torpor which grants additional energy savings [3-5]. Above changes in physiology and behavior are triggered by shortening day [6-8], and ultimately increase the probability to survive winter and reproduce in spring. However, there is a considerable variation in photoresponsiveness among individuals of the same species, or even within the same population $[9,10]$. Some individuals do not respond to changes in photoperiod (non-responding phenotype or non-responders), do not regress gonads, do not enter torpor, and do not change $m_{\mathrm{b}}$, what may lead to higher energy expenditure and eventually to higher costs of winter survival $[6,8,11,12]$. The proportion of non-responding individuals varies between species and may reach up to $80 \%$ in Prairie voles Microtus ochrogaster [13], 47\% in Turkish hamsters Mesocricetus brandti [14], 50\% in white footed mice Peromyscus leucopus [15] and $25 \%$ in deer mice Peromyscus maniculatus [16]. Despite the lack of direct evidence for higher survival of responding individuals (responders), previous studies showed that both, daily and seasonal torpor as well as reduction of normothermic body temperature may increase the life span by decreasing risk of predation $[17,18]$, reducing the overall cost of survival under challenging environmental conditions [17-19] or by reducing the rate of senescence [20-24]. Moreover, cessing reproduction in winter delays reproductive ageing by deceleration of the attrition of ovarian follicles [25], increase of litter size and decrease of the number of failed pregnancies [26]. If seasonal adjustments in physiology (including heterothermy) and behavior are considered beneficial to winter survival and reproductive success, natural selection should favor responding phenotype (responders), eventually leading to elimination of the non-responding one. Nevertheless, both phenotypes are maintained in populations [10, 27]. Place and Cruickshank [25] suggested, that individuals which respond to short photoperiod should have higher reproductive success than non-responding ones. However, to the best of our knowledge this prediction has not been experimentally verified. We hypothesized that winter phenotypes which differ in their strategy of managing energy resources, should also differ in life history traits. In line with that we predicted that different winter phenotypes are associated with different characteristics of life history traits, and that responding individuals commence reproduction later and deliver smaller litters with bigger offspring than non-responding ones. To verify it, and ultimately to test our hypothesis, we used Siberian hamster Phodopus sungorus which is highly seasonal rodent, but with a considerable among-individual variation in photoresponsiveness. On average, depending on a population, between 20 and $60 \%$ of individuals do not respond to short photoperiod and remain in their summer status throughout the year [28-32]. We used hamsters that were kept in pairs composed of individuals of the same phenotype (responders or non-responders) and measured time to first parturition, $m_{\mathrm{b}}$ of offspring and their growth rate in two consecutive litters. Additionally, we analyzed nest-building behavior as a trait that may differ between responders and non-responders, and which may be associated with differences in life history traits.

To inquire about the consequences of reproduction on future somatic maintenance, we analyzed parameters of oxidative stress and antioxidant defense in post-reproductive males and females. Imbalance between reactive oxygen species production and antioxidant defense leads to oxidative stress [33-36], which reflects the cost of somatic maintenance [37]. Since reproduction increases energy expenditure, it was hypothesized that it may lead to increased production of reactive oxygen species and eventually launch the protective mechanisms that limit oxidative damage [38-40]. High costs of antioxidant defense may in turn reduce further investment into somatic maintenance leading to oxidative stress [38, 41, 42]. However, available data on oxidative cost of reproduction are ambiguous, or even contradictory. On the one hand, it was reported that reproductive animals had increased oxidative stress (OS) $[38,43]$ and decreased antioxidant capacity (AC) [41, 42, 44, 45]. On the other hand, pregnancy and lactation was found to protect against OS [40, 46-48]. Other studies showed negative correlation between life history traits such as litter size or litter mass and OS [38, 49], and positive correlation between clutch size and $\mathrm{AC}$ [50]. Assuming that the type of response to winter may affect life history traits and therefore investment into reproduction, we predicted that responders and non-responders differ in their investment in somatic maintenance what would be reflected in different oxidative status after reproduction. Because in most mammals cost of reproduction for males is restricted to mate competition [51, 52], and in Siberian hamsters sire presence in the nest does not affect pup survival and development [53, 54], we also predicted that dams, which bear most of the reproduction cost, invest less into somatic maintenance after reproduction and may be a subject to oxidative stress. To test these predictions, we measured basal metabolic rate (BMR), $\mathrm{OS}$ and $\mathrm{AC}$ in reproductive and non-reproductive individuals of both phenotypes. 


\section{Results}

Life history traits in two phenotypes of Siberian hamster All hamsters gained body mass during breeding season (LME: $\left.\mathrm{F}_{(1,103.59)}=69.99, P<0.001\right)$, and $m_{\mathrm{b}}$ of males and females increased by 10 and 17\%, respectively (Table 1 ). Responders differed in $m_{\mathrm{b}}$ from non-responders only before breeding (LME: $\left.F_{(1,103.59)}=15.37, P<0.001\right)$, when responding individuals were smaller than non-responding ones (Table 1). There was also a significant interaction between reproductive status and sex $\left(\mathrm{LME}: \mathrm{F}_{(1,111.70)}=18.20\right.$, $P<0.001)$ and reproducing females weighted more than non-reproducing ones, while in males this relation was opposite (Table 2).

Litter size did not differ between consecutive litters (LME: $F_{(1,38)}=0.02, P=0.88$; Table 1$)$ and it ranged between one and eight pups. Also phenotypes did not differ in litter size $\left(\mathrm{LME}: \mathrm{F}_{(1,38)}=2.18, P=0.15\right.$; Table 1$)$.

Body mass of individual offspring was negatively related to litter size $\left(\mathrm{LME}: \mathrm{F}_{(1,44.84)}=4.68, P=0.04\right)$. Independent of the parental phenotype, mean $m_{\mathrm{b}}$ of individual pup increased with consecutive litters (LME: $F_{(1,107.41)}=$ 4.11, $P=0.04$ ). Offspring $m_{\mathrm{b}}$ increased with age (LME: $\left.\mathrm{F}_{(1,93.54)}=2156.80, P<0.001\right)$, but responding pairs delivered smaller offspring than non-responding ones (LME: $\mathrm{F}_{(1,48.46)}=5.97, P=0.002$; Table 1, Fig. $\left.1 \mathrm{a}-\mathrm{c}\right)$. The growth rate did not differ between phenotypes $\left(\mathrm{LME}: \mathrm{F}_{(1,93.54)}=\right.$
$0.84, P=0.36)$ resulting in smaller $m_{\mathrm{b}}$ at weaning in offspring of responders (Fig. $1 \mathrm{~d}$ ).

Phenotypes differed in the time of commencing breeding $(\mathrm{U}=20.00, P=0.008)$ but not in the time interval between consecutive litters $(U=20.00, P=0.12$; Table 1$)$. In both phenotypes dam $m_{\mathrm{b}}$ correlated neither with the time of first parturition (NR: $r=-0.65, \mathrm{~N}=8, P=0.08$; $\mathrm{R}: r=0.31, \mathrm{~N}=9, P=0.41)$ nor with the time interval between litters (NR: $r=0.02, \mathrm{~N}=8, P=0.97$; R: $r=-0.28$, $\mathrm{N}=9, P=0.47)$. However, among responders, bigger sires bred earlier than smaller ones $(r=-0.71, \mathrm{~N}=12, P=0.01)$ whereas there was no such relationship among non-responders $(r=0.26, \mathrm{~N}=10, P=0.47$; Fig. 2$)$. There was also no correlation between sire $m_{\mathrm{b}}$ and time interval between consecutive litters (NR: $r=-0.17, \mathrm{~N}=8$, $P=0.69 ; \mathrm{R}: r=-0.21, \mathrm{~N}=9, P=0.58)$.

\section{Nest-building behavior}

Both the proportion of using the paper tube as well as the propensity to build the nest were repeatable $(r=$ 0.46, 95\% CI $0.40-0.52, P<0.001$; and $r=0.25,95 \% \mathrm{CI}$ $0.10-0.38, P=0.05$; respectively). In winter both phenotypes increased the use of paper tube $\left(\mathrm{LME}: \mathrm{F}_{(1,218)}=\right.$ 83.10, $P<0.001$ ) and the propensity to build the nest $\left(X^{2}(1,296)=46.91, P<0.001\right)$, however, in responding individuals this increase was greater than in non-responding

Table 1 Comparison of life-history traits between winter phenotypes of Siberian hamster

\begin{tabular}{|c|c|c|c|}
\hline \multirow[b]{2}{*}{ Life history trait } & & \multicolumn{2}{|l|}{ Phenotype } \\
\hline & & responding & non-responding \\
\hline \multirow[t]{2}{*}{$m_{\mathrm{b}}$ before breeding $(\mathrm{g})$} & males & $26.81 \pm 3.74$ & $32.66 \pm 3.56^{a}$ \\
\hline & females & $23.04 \pm 2.11$ & $24.97 \pm 2.61^{a}$ \\
\hline \multirow{2}{*}{$m_{\mathrm{b}}$ after breeding $(\mathrm{g})$} & males & $32.79 \pm 3.37$ & $34.13 \pm 3.62$ \\
\hline & females & $30.02 \pm 4.30$ & $28.22 \pm 3.32$ \\
\hline \multirow[t]{2}{*}{ litter size } & $1 \mathrm{st}$ & $5.33 \pm 1.61$ & $4.20 \pm 2.04$ \\
\hline & $2 \mathrm{nd}$ & $5.11 \pm 2.20$ & $4.60 \pm 1.51$ \\
\hline \multirow[t]{3}{*}{ offspring $m_{\mathrm{b}}(\mathrm{g})$} & 3 days & $2.56 \pm 0.31$ & $2.94 \pm 0.40^{a}$ \\
\hline & 10 days & $6.43 \pm 0.82$ & $6.97 \pm 0.92^{a}$ \\
\hline & 18 days & $12.65 \pm 1.85$ & $13.45 \pm 1.79^{a}$ \\
\hline \multirow[t]{2}{*}{ growth rate $\left(\mathrm{g}_{\text {day }}{ }^{-1}\right.$ ) } & $1 \mathrm{st}$ & $0.65 \pm 0.12$ & $0.69 \pm 0.11$ \\
\hline & $2 \mathrm{nd}$ & $0.71 \pm 0.11$ & $0.71 \pm 0.11$ \\
\hline time of commencing breeding (days) & & $36.50 \pm 3.56$ & $22.00 \pm 2.24^{a}$ \\
\hline time interval between consecutive litters (days) & & $27.00 \pm 5.28$ & $38.50 \pm 4.92$ \\
\hline \multirow[t]{2}{*}{ degree of use of paper tube \% } & winter & $87.10 \pm 12.04$ & $77.78 \pm 16.49^{a}$ \\
\hline & summer & $66.74 \pm 20.24^{b}$ & $67.67 \pm 24.72^{b}$ \\
\hline \multirow[t]{2}{*}{ propensity to build the nest \% } & winter & 91.30 & $72.50^{a}$ \\
\hline & summer & $30.40^{b}$ & $43.10^{b}$ \\
\hline
\end{tabular}

Values are mean \pm SD or median \pm SE in case of time of commencement to breeding and time interval between consecutive litters

a difference between phenotypes; $P \leq 0.05$

${ }^{\mathrm{b}}$ difference between seasons within phenotype; $P \leq 0.05$ 
Table 2 Comparison of life-history traits between breeding and non-breeding Siberian hamsters

\begin{tabular}{llll}
\hline & \multicolumn{3}{c}{ Phenotype } \\
\cline { 3 - 4 } Life history trait & & breeding & non-breeding \\
\hline$m_{\mathrm{b}}$ before breeding $(\mathrm{g})$ & males & $30.17 \pm 4.54$ & $31.95 \pm 4.36$ \\
& females & $24.72 \pm 2.71$ & $23.95 \pm 2.44$ \\
$m_{\mathrm{b}}$ after breeding (g) & males & $32.37 \pm 2.62$ & $35.87 \pm 3.87^{\mathrm{a}}$ \\
& females & $30.12 \pm 3.42$ & $26.65 \pm 3.03^{\mathrm{a}}$ \\
degree of use of paper tube \% & winter & $84.20 \pm 12.81$ & $74.55 \pm 18.57$ \\
& summer & $68.82 \pm 20.86$ & $64.02 \pm 27.14$ \\
propensity to build the nest \% & winter & 88.3 & $61.1^{\mathrm{a}}$ \\
& summer & $43.6^{\mathrm{b}}$ & $31.5^{\mathrm{b}}$
\end{tabular}

Values are mean \pm SD

${ }^{a}$ difference between reproductive status; $P \leq 0.05$

${ }^{\mathrm{b}}$ difference between seasons within reproductive status; $P \leq 0.05$

ones (degree of using paper tube: LME: $\mathrm{F}_{(1,218)}=10.61$, $P=0.001$; propensity to build the nest: $X_{(1,148)}^{2}=6.58$, $P=0.01$, Table 1). Non-breeding individuals tended to use paper tubes slightly less than breeding ones (LME: $\left.\left.\quad \mathrm{F}_{(1,} \quad 70\right)=2.99, \quad P=0.09\right)$. Breeding and non-breeding hamsters differed in their propensity to build the nest only in winter $\left(X^{2}(1,148)=14.96\right.$,
$P<0.001)$, while in summer, the percentage of hamsters building the nest was similar (Table 2).

\section{BMR and oxidative status}

Mean parental BMR equaled $0.27 \pm 0.01 \mathrm{~W}$ and correlated with hamster $m_{\mathrm{b}}\left(\mathrm{GLM}: \mathrm{F}_{(1,81)}=6.59, P=0.012\right)$. After adjusting for $m_{\mathrm{b}}$, BMR did not differ between reproducing and non-reproducing individuals (GLM: $\left.\mathrm{F}_{(1,81)}=2.17, P=0.14\right)$, between sexes $\left(\mathrm{GLM}: \mathrm{F}_{(1,81)}=\right.$ $0.01, P=0.93)$ or between phenotypes $\left(\mathrm{GLM}: \mathrm{F}_{(1,81)}=\right.$ $0.19, P=0.66$; Fig. 3, Table 3).

Concentration of ROM did not differ between reproducing and non-reproducing hamsters $\left(G L M: F_{(1,70)}=\right.$ 0.36, $P=0.55)$, but it differed between phenotypes $\left(\right.$ GLM: $\left.F_{(1,70)}=6.80, P=0.01\right)$ and sexes $\left(G L M: F_{(1,70)}\right.$ $=6.60, P=0.01$; Fig. 4 a). Responders had higher concentration of ROM than non-responders and in males it was higher than in females. These differences most probably resulted from high concentration of ROM in responding males $\left(\mathrm{GLM}: \mathrm{F}_{(1,70)}=6.24, P=0.01\right.$; Table 3$)$. Biological antioxidant potential did not differ between hamsters of different reproductive status $\left(\mathrm{GLM}: \mathrm{F}_{(1,70)}=\right.$ 1.37, $P=0.25)$ or between phenotypes $\left(G L M: F_{(1,70)}=\right.$ $0.01, P=0.96$; Fig. 4 b). However, there was an effect of sex on BAP $\left(\operatorname{GLM}: F_{(1,70)}=5.32, P=0.02\right)$, and in males

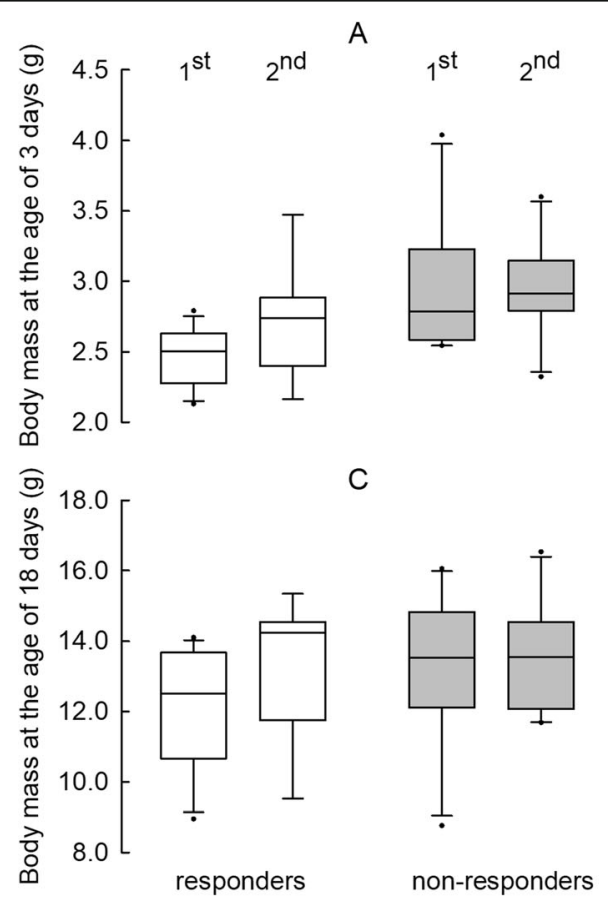

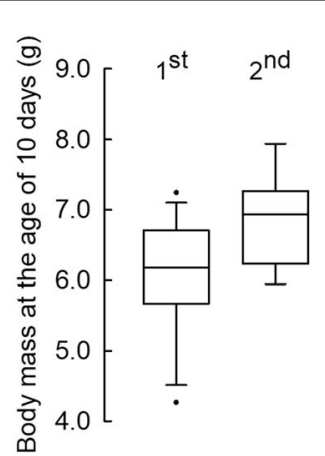

B
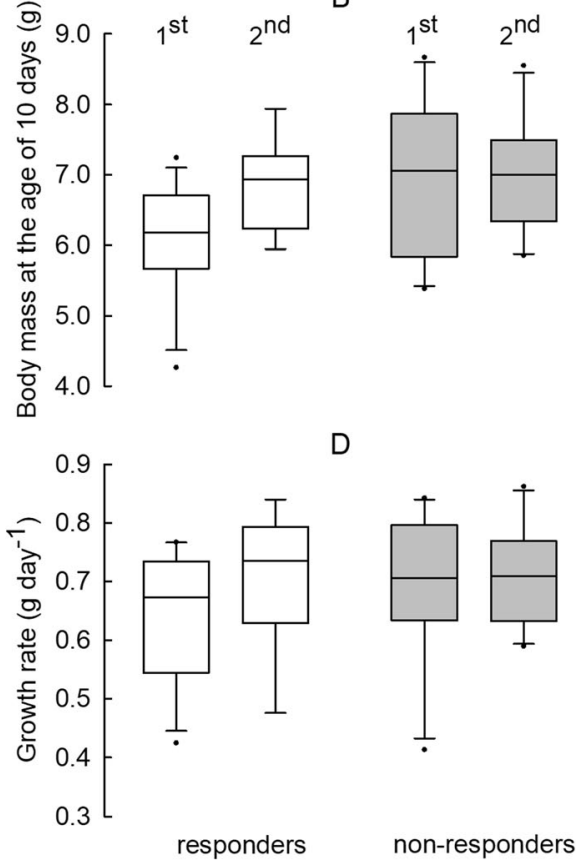

D

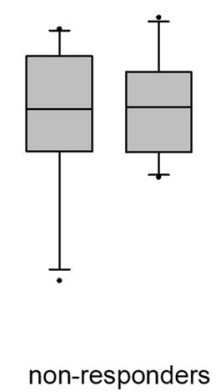

Fig. 1 Life history traits (a: body mass at the age of 3 days; $\mathbf{b}$ : body mass at the age of 10 days; $\mathbf{c}$ : body mass at the age of 18 days; $\mathbf{d}$ : mean daily growth rate between $3^{\text {rd }}$ and $18^{\text {th }}$ day of life) in responding and non-responding pairs. Ordinal numbers above figures indicate consecutive litters. Lines inside boxes indicate median, while boxes cover the 25th to 75th percentiles. Whiskers indicate maximum value below upper fence and minimum value above lower fence. Dots indicate outliers 


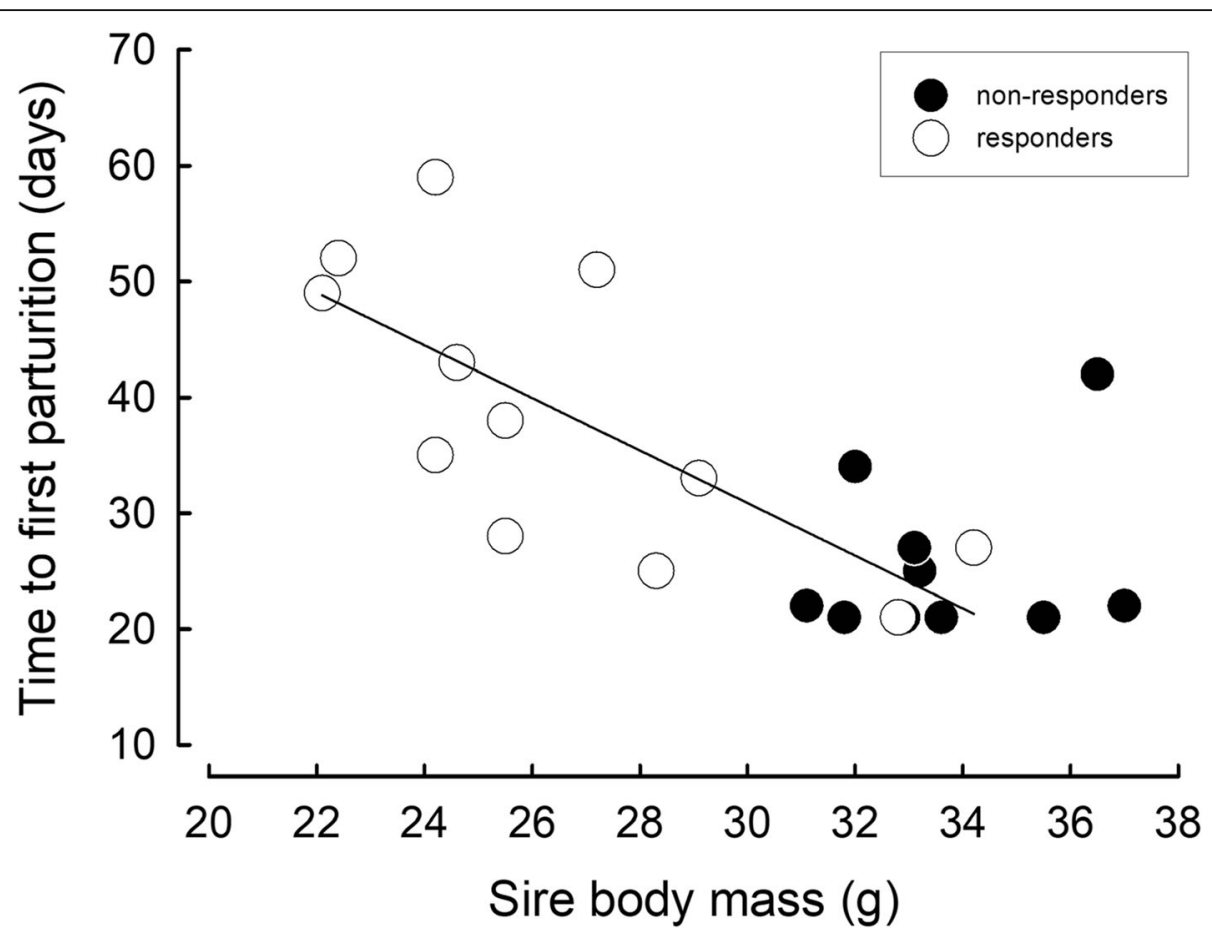

Fig. 2 Relationship between sire body mass and time to first parturition in responding and non-responding hamsters. Regression line $(y=-2.27 x+$ $\left.99.00, r^{2}=0.50, F_{(1,10)}=10.03, P=0.01\right)$ indicates relationship between sire body mass and time to the first parturition in responding hamsters

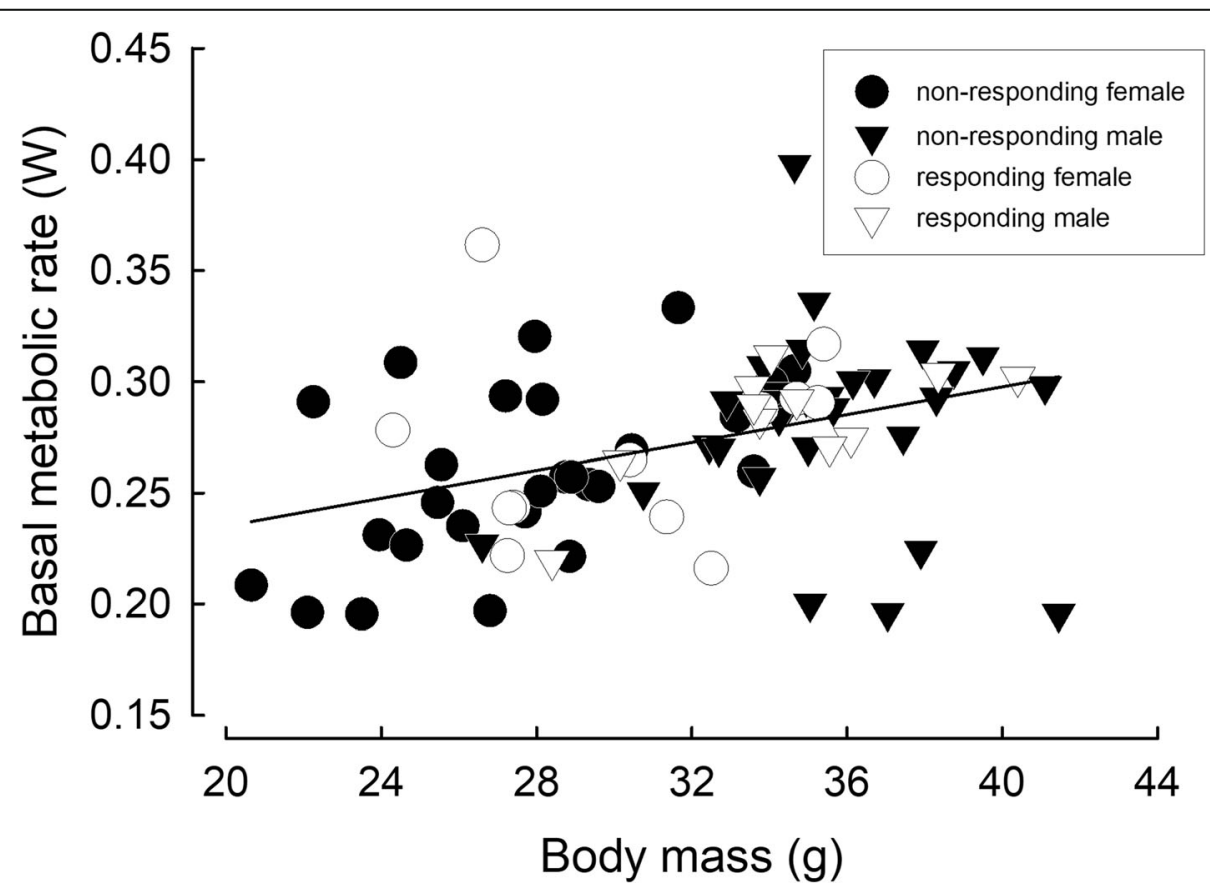

Fig. 3 Relationship between basal metabolic rate and body mass $\left(y=0.003 x+0.17, r^{2}=0.14, F_{(1,79)}=13.38, P<0.001\right)$ in responding and nonresponding Siberian hamsters 
Table 3 Comparison of basal metabolic rate and oxidative status between winter phenotypes of Siberian hamster

\begin{tabular}{|c|c|c|c|}
\hline \multirow[b]{2}{*}{ Life history trait } & & \multicolumn{2}{|l|}{ Phenotype } \\
\hline & & responding & non-responding \\
\hline Basal metabolic rate (W) & & $268 \pm 0.009$ & $273 \pm 0.005$ \\
\hline \multirow[t]{2}{*}{ Reactive Oxygen Metabolites $\left(\mathrm{mg} \mathrm{dL}^{-1}\right.$ ) } & male & $15.50 \pm 8.00$ & $9.71 \pm 1.54^{\mathrm{a}}$ \\
\hline & female & $10.77 \pm 1.88^{b}$ & $9.67 \pm 2.91$ \\
\hline \multirow[t]{2}{*}{ Biological Antioxidant Potential ( $\mu \mathrm{M}$ Vit- $\mathrm{C} \mathrm{L}^{-1}$ ) } & male & $3525.98 \pm 360.47$ & $3596.77 \pm 237.59$ \\
\hline & female & $3517.56 \pm 655.83^{b}$ & $3230.47 \pm 608.63^{b}$ \\
\hline
\end{tabular}

Values are mean $+S D$ or marginal mean $\pm S E$ in case of Basal metabolic rate

a difference between reproductive status; $P<0.05$

${ }^{\mathrm{b}}$ difference between sexes within phenotype; $P<0.05$

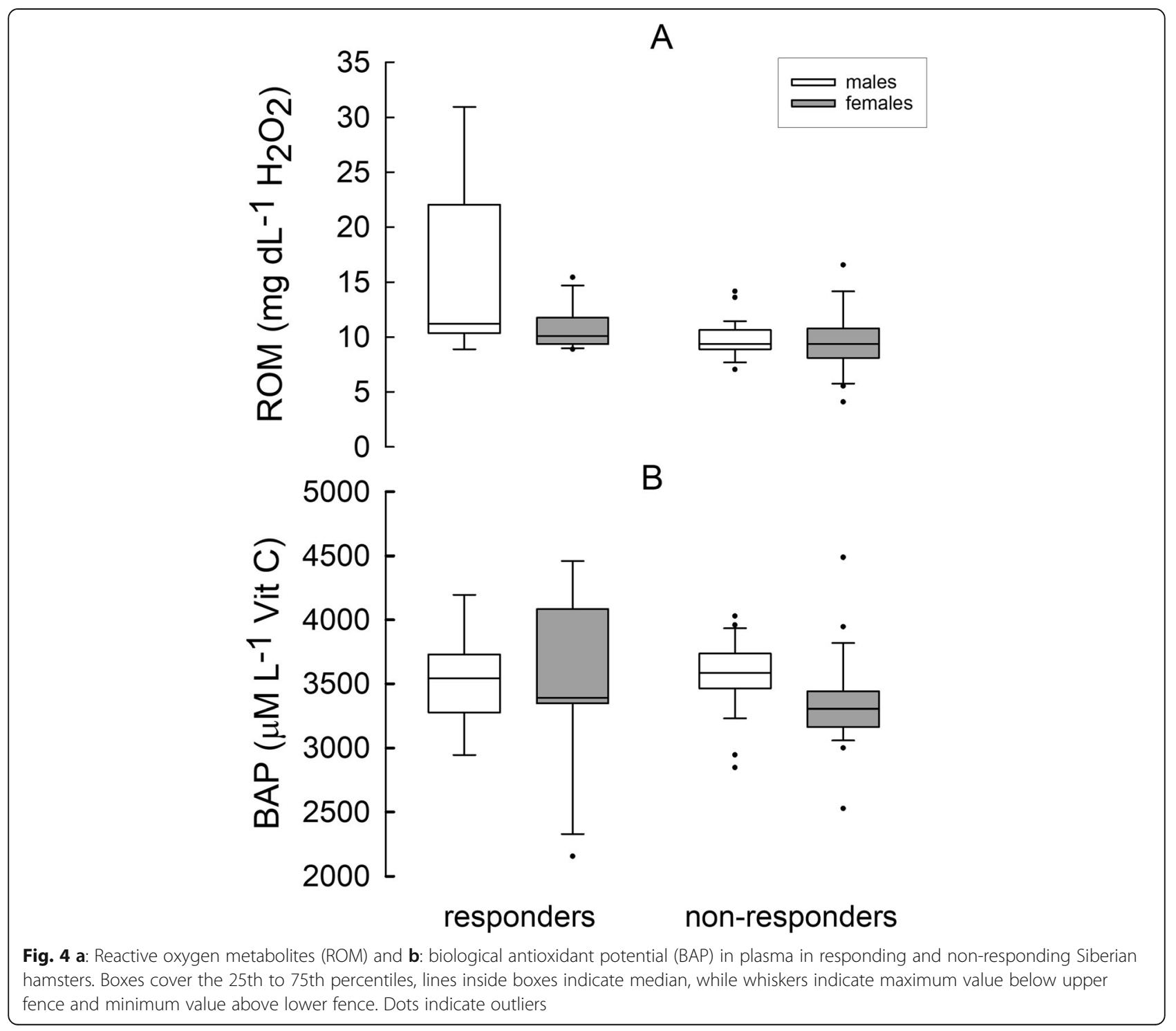


of both phenotypes BAP was higher than in females (Table 3).

\section{Discussion}

In small mammals of the Temperate-Zone seasonal adjustments, including gonadal regression, molting to winter coat and heterothermy reduce energy expenditure in winter. Previous studies suggested that individuals which respond to winter photoperiod may have longer life span, and higher reproductive success than non-responding ones $[17,21,25,55]$. Here we aimed to test the hypothesis that different strategies of surviving winter are related to differences in life history traits. To do so, we compared reproductive characteristics of two phenotypes of Siberian hamsters - responding and non-responding to seasonal changes in day length. We also analyzed the relationship between reproduction, energy metabolism, and oxidative status in this species.

\section{Effect of phenotype on life history traits}

Out of the studied population we created 11 pairs of responding and 29 pairs of non-responding hamsters. All pairs of responders bred successfully, while among non-responders 17 pairs did not breed at all. A possible explanation for that could be different rate of aging in both phenotypes. Previous studies which showed delayed reproductive ageing in individuals maintained under short photoperiod provide indirect support for this hypothesis [25, 26]. Place and Cruickshank [25] suggested that non-responders age faster than responders and found that female Siberian hamsters responding to short days had greater number of ovarian primordial follicles at older age than non-responding ones. Our animals were about one year old when paired. In a closely related species, the Djungarian hamster Phodopus campbelli, symptoms of reproductive aging occured already in 6-month old animals, and in 8-month-olds fertility (delivery success) and fecundity (litter size and weaning success) were reduced by half [56]. Thus, it is possible that our non-responding individuals were reproductively older than responding ones. One could argue that another reason for not breeding of non-responders was low $m_{\mathrm{b}}$ of non-breeding females. They were $\sim 15 \%$ lighter than the breeding ones and after winter-like acclimation they increased $m_{\mathrm{b}}$ slower than breeding females (Table 2). However, this explanation seems unlikely because at the same time some of breeding females were as small as non-breeding ones.

We found a clear correlation between photoresponsiveness and time to first reproduction. Individuals of the photo-responding phenotype commenced breeding about two weeks later than non-responding ones (Table 1). Arguably, delayed breeding in responders resulted from gonadal regression in this phenotype $[8,57,58]$. Likewise, in some hibernating species, e.g. golden-mantled ground squirrels Callospermophilus lateralis and Richardson's ground squirrels Urocitellus richardsonii, males terminate hibernation even a month before females to rebuild gonads and $m_{\mathrm{b}}$ prior to breeding season [59, 60]. In responding Siberian hamsters time of commencement of breeding correlated negatively with sire body mass - smaller responding males required more time to achieve reproductive activity (Fig. 2). Although hamsters may mate on the day of parturition, the second litter is usually delayed [61]. Here, independent of phenotype, most animals delivered second litter within $\sim 32$ days after delivery of the first one. There was also no difference between responders and non-responders in the litter size (Table 1). In both phenotypes it was $\sim 5$ pups, that is within the typical range for Siberian hamsters $[54,62,63]$. In the same species Place an co-authors [26] found that dams which responded to short photoperiod produced bigger litters than non-responding ones, but in that study non-responsiveness was induced by pinealectomy. In our study, independent of the parental phenotype, the growth rate of pups was $\sim 0.7 \mathrm{~g}$ per day which corresponds to a range reported previously for this species $\left(0.56-0.94 \mathrm{~g} \mathrm{day}^{-1}\right.$, depending on ambient temperature and litter size) [54, 61-63]. Because males were in the nests only with the first litters, and the growth rates were similar in both litters, these results support previous findings that in Siberian hamsters presence of a sire does not affect offspring growth rate or pup survival [53].

Despite similar litter size and offspring growth rate, responders delivered smaller pups than non-responders, and this difference was maintained until weaning (Table 1). Offspring mass increased with subsequent litters (Fig. 1a-c), most probably as a result of increasing $m_{\mathrm{b}}$ of dams, which were $15 \%$ heavier at the end of reproduction than just before the start of breeding. In Djungarian hamsters offspring mass increased with dam age, whereas litter size decreased [56]. Positive relationship between maternal size and offspring size (MSOS) is common among species, from invertebrates to vertebrates $[64,65]$. The source of MSOS correlation is still debatable, however it is possibly related to maternal age, nutritional status and body condition [66]. Most data for the positive effect of sire $m_{\mathrm{b}}$ and paternal care on offspring condition come from avian studies [67-69], but there is also strong evidence for Djungarian hamsters [53, 54, 61, 63, 70-72]. Conversely, in Siberian hamsters the presence of male in the nest is not necessary and does not affect pup survival and development [53].

In individually kept hamsters there were no differences between males and females in nest building behavior (Table 1). During summer acclimation number of animals that built a nest from paper tube supplied to the cage, or the degree of chewing it, did not differ between 
sexes or phenotypes. However, after acclimation to winter-like conditions among responders more individuals built nests and chew more paper tubes than among non-responders. Apparently, this correlated with smaller $m_{\mathrm{b}}$ of responders, who presumably used their nest to increase thermal insulation.

\section{BMR and oxidative status}

Investment into reproduction requires significant increase in metabolism [38, 73, 74]. Female laboratory Swiss mice selected for high BMR produced more milk and presented better parental care, measured as the offspring growth rate, than mice with low BMR $[75,76]$, whereas eastern chipmunks Tamias striatus with higher daily energy expenditure produced bigger litters [74]. However, in C57 mice [77] and in Siberian hamsters (this study) breeding and non-breeding individuals did not differ in BMR. Similarly, there was no difference between responders and non-responders (Table 3 ). One could argue that this lack of difference was an effect of measuring metabolism even a month after weaning of the last litter. However, McLean and Speakman [78] found that elevated metabolism in female brown long-eared bats Plecotus auritus was maintained even 80 days after weaning. Thus, we argue that Siberian hamsters did not increase BMR during reproduction. It agrees with the results showing that reproduction is not demanding for animals in natural environments [42, 44, 79, 80]. In many species dams adjust litter size or offspring mass to their current parental efficiency, therefore only forced increase of reproduction costs (e.g. enlarged litter size) would lead to increased metabolism [81-83].

The theory of increased susceptibility to oxidative stress during pregnancy and lactation has a long history $[45,84]$, however its experimental support is ambiguous. Increase of metabolism and ROM generation not necessarily result in oxidative stress [40, 46]. In reproducing laboratory mice oxidative damage increased in plasma [49] but decreased in liver [38, 49]. In bank voles Myodes glareolus reproduction led even to decrease of oxidative damage to lipids but did not change the oxidative damage to proteins [46]. Moreover, oxidative stress increased with litter size in mice [38] and eastern chipmunks [74], but not in bank voles [46] or canaries Serinus canaria [40]. Relationship between antioxidant capacity and reproduction is also equivocal. Reproducing mice showed lower [85], higher [38], or unchanged [48] activity of antioxidant enzymes. Antioxidant capacity increased with number of nestlings in male zebra finches Taeniopygia guttata, but decreased in females [41], decreased in both sexes of great tits Parus major [42], but did not change in striped hamsters Cricetulus barabensis [43].
Oxidative stress may also be understood as a proxy for somatic maintenance - increasing when resources available for somatic maintenance are insufficient [37, 40]. Based on our initial prediction that responders and non-responders differ in life history traits, we expected differences in their oxidative status after reproduction $[37,86]$. However, we neither found differences between phenotypes in ROM concentration nor in BAP (Table 3, Fig. 4). We also did not find differences between breeding and non-breeding individuals. Under limited resource availability reproduction comes at a cost of self-maintenance, what may result in lower investment in antioxidant defense and eventually in oxidative stress [33-36, 39, 86, 87]. According to the theory of ageing, the loss of cell function during senescence is triggered by a shift in the redox state of the cell and oxidative damage induced by free radicals $[88,89]$. This could result in accumulating deleterious mutations and shortening life span $[88,90]$. Indeed, negative relationship between investment in reproduction and longevity was well established ([91-95], but see [96, 97]). In contrast, heterothermy use was considered to extend life span $[17,18,20-23]$ and to reduce the extinction risk [19]. Moreover, even a small decrease in body temperature may lead to lower oxidative stress and may increase life span, as in transgenic mice with normothermic body temperature lower by $0.5{ }^{\circ} \mathrm{C}$ than in wild-type C57/BL6 mice [24]. Siberian hamsters kept under short days not only enter daily torpor but also decrease their normothermic body temperature by $\sim 0.7$ ${ }^{\circ} \mathrm{C}$ [98]. However, we found no differences in oxidative status between individuals which were using daily torpor during acclimation to winter-like conditions (responders) and those which were not (non-responders). All individuals had similar ROM and BAP levels, apart from responding males which had 50\% higher ROM concentration (Table 3). On the one hand this could result from the higher growth rate after winter-like acclimation in responders than in non-responders, but on the other hand it suggests impaired somatic maintenance in post-reproductive period. Higher ROM concentration only in responding males suggests that their antioxidant defense was less effective than in females, which could have been protected by antioxidant properties of estrogens $[99,100]$. Yet, overall, males had higher BAP level than females (Fig. 4), suggesting that despite higher ROM concentration, responding males were not subjected to oxidative stress during reproduction.

\section{Conclusions}

To the best of our knowledge this study is the first attempt to compare the reproductive characteristics of phenotypes of the same species which differ in their response to short photoperiod. On the one hand, cessation 
of reproduction in winter and $m_{\mathrm{b}}$ reduction in responding animals delayed commencement of breeding and resulted in smaller offspring $m_{\mathrm{b}}$. On the other hand, the number of non-breeding non-responders suggests that they aged faster than responders. Despite above differences in life history characteristics, both phenotypes did not differ in metabolic rate and oxidative status, suggesting no effect of reproduction on future investment in somatic maintenance. Delayed breeding in responding pairs and high post-reproductive ROM concentration in male responders support our hypothesis that differences in the adjustment to winter conditions result in different characteristics of life history traits. Because litter size and growth rate were the same in responders and non-responders, and assuming the same resource availability for both phenotypes, we propose that despite differences in the strategy of managing energy resources in winter, they achieve similar fitness, what may explain coexistence of both phenotypes in the population.

However, here we compared only two extreme phenotypes, responding and non-responding to short photoperiod, whereas within one population of Siberian hamsters we can observe entire spectrum of winter phenotypes [101]. Such polymorphism may be beneficial in stochastic environments, where environmental conditions may differ between winters. We propose that non-responding phenotype may be particularly beneficial during mild winters, in the environment with abundant energy supplies and immediate access to food after winter. Responders would be favored during harsh winters, when energy savings mechanisms (e.g. decrease in $m_{\mathrm{b}}$, gonadal regression and daily torpor) are the most important phenotypic adjustments. If so, from an evolutionary point of view, none of the phenotypes would be impaired when compared to another and polymorphism would be maintained in population.

\section{Methods}

All experimental procedures were approved by the Local Committee for Ethics in Animal Research in Bydgoszcz, Poland (decisions nos. 3/2015, 31-33/2015, 35/2015).

\section{Animals and housing}

We used Siberian hamsters from the outbred colony maintained at the Department of Biology and Environmental Protection at Nicolaus Copernicus University in Toruń, Poland. After birth animals were kept under summer-like conditions, i.e. at ambient temperature $\left(T_{\mathrm{a}}\right)=$ $18 \pm 2{ }^{\circ} \mathrm{C}$ and long photoperiod (16 L:8 D) for 4 months. Then, to induce change to winter phenotype, animals were transferred to winter-like conditions $\left(T_{\mathrm{a}}=10 \pm 2{ }^{\circ} \mathrm{C}\right.$ and short photoperiod (8 L:16 D)) for 3 months. After completing the acclimation to winter-like conditions hamsters were transferred to summer-like conditions again and 2 weeks later they were paired for breeding. Animals were fed with standard rodent food (Labofeed, Morawski, Kcynia, Poland) and supplied with drinking water ad libitum.

\section{Defining winter phenotypes}

Winter phenotypes were determined based on fur coloration and use of torpor. A hamster was classified as responding if it at least partially changed fur color and entered at least one episode of torpor (subcutaneous temperature; $T_{\mathrm{sc}} \leq 32^{\circ} \mathrm{C}$ ), and as non-responding if it remained grey and did not enter torpor throughout winter. Animals that showed only one trait of winter phenotype (i.e. only white fur or only torpor) were classified as partial responders [101] and were excluded from analyses. To assess the use of torpor, we monitored individuals' $T_{\mathrm{sc}}$ with miniature data loggers. Loggers (model TL3-1-27; accuracy of $0.3{ }^{\circ} \mathrm{C}$ between $0{ }^{\circ} \mathrm{C}$ and $45^{\circ} \mathrm{C}$, constructed by Dr. Dmitry Petrovski, Russian Academy of Sciences, Novosibirsk, Russia) weighted $\sim 0.8 \mathrm{~g}$ and allowed downloading data wirelessly. Before implantation, loggers were pre-calibrated against a precise mercury-in-glass thermometer between $15^{\circ} \mathrm{C}$ and $40^{\circ} \mathrm{C}$. After $\sim 6$ weeks of winter acclimation loggers were implanted subcutaneously into the interscapular region under ketamine (40 $\mathrm{mg} \mathrm{kg}^{-1}$; Ketamina $10 \%$, Biowet, Puławy, Poland) and xylazine $\left(8 \mathrm{mg} \mathrm{kg}^{-1}\right.$; Sedazin $2 \%$, Biowet, Puławy, Poland) anesthesia. The incisions were closed with absorbable sutures (Safil 5/0, Aesculap AG, Tuttlingen, Germany). After surgery all hamsters were kept in the laboratory for 1 day in individual cages (under short photoperiod but $T_{\mathrm{a}}=22^{\circ} \mathrm{C}$ ) and then were transferred back to the animal facility room. Subcutaneous temperature was recorded every $10 \mathrm{~min}$ and downloaded every 2 weeks.

\section{Life history traits}

Two weeks after changing conditions to summer-like hamsters $(\sim 1$ year old $)$ were paired into 40 phenotypically-matching pairs composed of responding or non-responding hamsters (11 pairs of responders and 29 pairs of non-responders). All animals were weighed before being paired and also after birth of the second litter (sires) or after weaning of the second litter (dams). Animals remained paired for 14 weeks or until delivery of the second litter. Immediately after birth of the second litter, males were separated from females to prevent further breeding. Eventually, 12 pairs of non-responding hamsters and 11 pairs of responding hamsters bred successfully and delivered at least one litter. Seventeen out of non-responding pairs did not breed at all and these animals were used as a control group in the analyses of the cost of reproduction. Then we determined life history traits associated with reproduction: time of commencement of breeding, time interval between consecutive litters, litter size, mass of litter 
at 3rd, 10th and 18th day of life and growth rate of offspring. Whole litters were weighed together, to the nearest $0.1 \mathrm{~g}$ (SPU402, OHAUS, Parsippany, NJ, USA) and mean $m_{\mathrm{b}}$ of individual offspring was calculated as total mass of the litter divided by number of offspring.

\section{Nest-building behavior}

During acclimation to summer- and winter-like conditions, before mating, nest-building behavior tests were done in individual hamsters twice in each season (10 days apart). Toilet paper tubes were used as a nesting material. Paper tubes $(\sim 5.50 \mathrm{~g}, \sim 10 \mathrm{~cm}$ length and $\sim 3$ $\mathrm{cm}$ in diameter) were dried for $72 \mathrm{~h}$ at $50^{\circ} \mathrm{C}$, weighed, and put into the animal's home cage. After $48 \mathrm{~h}$, non-chewed remains of tubes were collected, dried for $72 \mathrm{~h}$, and weighed to calculate the proportion of tube chewed by a hamster. In addition, we analyzed the propensity of animals to build a nest. We did not assess the complexity of nest structure but considered any roundish pile of paper pieces with a visible print of animal's body as a nest.

\section{Oxidative stress and antioxidant capacity}

At least 2 weeks, but not later than 6 weeks after weaning of the second litter we measured $\mathrm{OS}$ and $\mathrm{AC}$ in plasma. In non-reproducing pairs oxidative status was assessed at the same time as in reproducing ones. OS and AC were measured using Free Radical Analytical System (FRAS4 evolvo, H\&D, Parma, Italy; henceforth: $H \& D)$. This system measured the concentration of reactive oxygen metabolites (ROM) and biological antioxidant potential (BAP) in plasma. ROM concentration was measured with dROM-kit (d-ROM-kit, REDOX Kit; H\&D) as a level of total $\mathrm{H}_{2} \mathrm{O}_{2}$, and BAP was measured using PAT-kit (Plasma Antioxidant Test, REDOX Kit; H\&D) as a vitamin $\mathrm{C}$ concentration. Blood sample $(\sim 100 \mu \mathrm{l})$ was taken from the retro-orbital sinus by capillary puncture. Immediately after bleeding we applied analgesic eye drops into hamster's eye (Alcaine $5 \mathrm{mg} / \mathrm{ml}$, Alcon Polska, Warsaw, Poland).

\section{Basal metabolic rate}

Basal metabolic rate was measured at least 2 weeks, but not later than 4 weeks, after weaning of the last litter or after separation of control pairs by indirect calorimetry using an open-flow respirometry system (Sable Systems International, Las Vegas NV, USA; henceforth: SSI). Gas exchange was measured for $\sim 8 \mathrm{~h}$ within the thermoneutral zone of Siberian hamsters (at $29 \pm 1{ }^{\circ} \mathrm{C}[102,103]$ ) and BMR was calculated as the lowest rate of $\mathrm{O}_{2}$ consumption during $3 \mathrm{~min}$ in two last hours of the test. All data were acquired using ExpeData software (SSI) at 0.5 Hz. During measurement animals were sealed in $0.85 \mathrm{~L}$ respirometry chambers made of transparent polypropylene food containers (HPL 808, Lock\&Lock, Hana Cobi,
South Korea) which were placed in a temperature controlled cabinet (ST-1200, Pol-Eko-Aparatura, Wodzisław Śląski, Poland). Because BMR measurement requires post-absorptive conditions, hamsters did not have access to water and food during the measurement. Previously we found that this period was sufficient to ensure post-absorptive conditions in the species [103]. We used two parallel respirometry systems, which allowed to simultaneously measure 14 individuals.

Air was pulled from outside the building using air pump (5HCE-10-M553, Gast Manufacturing, Benton Harbor, MI, USA) and compressed in a balloon. Then air was dried and scrubbed of $\mathrm{CO}_{2}$ with a PureGas Generator (Puregas, Westminster, CO, USA). The main air stream was then split into chambers and a reference gas stream. Air flow rate $\left(\sim 330 \mathrm{~mL} \mathrm{~min}^{-1}\right)$ was regulated upstream of each respirometry chamber with a precise needle valve. Air streams leaving the respirometry chambers were selected sequentially with a computer-controlled multiplexer (Intelligent Multiplexer V3, SSI) and flow rate was measured downstream with a mass flow meter (FlowBar-4, SSI). After flow measurement, air stream was subsampled at a rate of $\sim 100 \mathrm{~mL} \mathrm{~min}^{-1}$ and water vapor pressure was measured (RH-300, SSI., USA). Then air stream was pulled through a nafion dryer tubes (product number 17049, VacuMed, Ventura, CA, USA) embedded in silica gel and finally was dried with magnesium perchlorate (product number 11636.36, VWR International, Gdańsk, Poland). Then concentrations of $\mathrm{O}_{2}$ and $\mathrm{CO}_{2}$ were measured. Oxygen consumption rate $\left(\dot{V} \mathrm{O}_{2}\right)$ and $\mathrm{CO}_{2}$ production rate $\left(\dot{V} C_{2}\right)$ of seven individuals were measured with FoxBox-C integrated $\mathrm{CO}_{2}$ and $\mathrm{O}_{2}$ analyzer (SSI). In the remaining seven hamsters we used FC10a analyzer (SSI) and CA10 analyzer (SSI) to measure $\dot{V} \mathrm{O}_{2}$ and $\dot{V} \mathrm{CO}_{2}$, respectively. Gas exchange of each animal was recorded for $5 \mathrm{~min}$, every $44 \mathrm{~min}$ and the baseline gas concentration readings were done every $20 \mathrm{~min}$. Metabolic rate was calculated after Lighton and coauthors [104] as follows:

$$
M R(W)=\frac{\dot{V} O_{2}(16+5.164 \times R E R)}{60}
$$

where $\dot{V} \mathrm{O}_{2}$ is the rate of oxygen consumption $\left(\mathrm{ml} \mathrm{O}_{2} / \mathrm{min}\right)$ and $R E R=\frac{\dot{V} C O_{2}}{\dot{V} O_{2}}$ was calculated from recorded $\dot{V} C O_{2}$ and $\dot{V} \mathrm{O}_{2}$. All individuals, regardless of phenotype and sex, had similar RER ranging between $0.79 \pm 0.03$ in summer and $0.83 \pm 0.05$ in winter.

\section{Statistical analysis}

We divided animals into two groups reflecting reproductive status: breeding and non-breeding animals. Animals in the latter group were paired but for unknown reasons did not breed. Only non-responding individuals did not breed. 
To analyze whether phenotype and reproductive status affect parental $m_{\mathrm{b}}$ before and after breeding, we used linear mixed model (LME) with animal ID as a random factor, phenotype, sex, reproductive status and time of measurement (before or after breeding) as fixed factors and two interactions: sex $\times$ reproductive status and phenotype $\times$ time of measurement.

To analyze the effect of phenotype on litter size and offspring $m_{\mathrm{b}}$, we used LME with pair ID set as a random factor. Consecutive litter number and parental phenotype were used as fixed factors. Additionally, in the model analyzing offspring $m_{\mathrm{b}}$ we used litter size and day of measurement (3rd, 10th or 18th) as a covariates. We used the day of $m_{\mathrm{b}}$ measurement as a continuous variable, to obtain information about the body mass gain (growth rate). Model included also two interactions: parental phenotype $x$ day of measurement and parental phenotype $\times$ litter size. We did not include dam and sire $m_{\mathrm{b}}$ in the analysis because of its non-significant effect on litter size (dam: $\mathrm{F}_{(1,19.17)}=0.03, P=0.87$; sire: $\mathrm{F}_{(1,19.28)}$ $=0.10, P=0.76)$ and offspring $m_{\mathrm{b}}\left(\right.$ dam: $\mathrm{F}_{(1,18.26)}=0.46$, $P=0.50$; sire: $\left.\mathrm{F}_{(1,17.99)}=0.80, P=0.38\right)$.

Because of small sample size and non-normal distribution of data, effect of phenotype on time of commencement of breeding and time interval between consecutive litters were analyzed by Mann-Whitney U test. Medians were compared by Mood's median test. We used Pearson correlation to relate time of commencement of breeding and time interval between consecutive litters with $m_{\mathrm{b}}$ of dams and sires, separately for responders and non-responders.

To analyze the effect of reproduction and phenotype on BMR, ROM concentration and BAP we used General Linear Model (GLM) with phenotype, sex, and reproductive status as fixed factors. In the model analyzing the variability of BMR we used $m_{\mathrm{b}}$ as covariate. The initial models included also interaction of sex and phenotype, but finally, this interaction was excluded, except for the model analyzing the variability of ROM concentration.

Repeatability of the proportion of paper tube chewed by individual was calculated with LME, and repeatability of propensity to build the nest was calculated with Generalized Linear Mixed Model (GLMM) and binary probit model. To test if phenotype and breeding status affect nest-building behavior we used LME with ID as a random factor, sex, phenotype, breeding status, season and trial as fixed factors, and interactions: phenotype $\times$ season and season $\times$ trial. To test if phenotypes differ in ability to build the nest we used contingency table using Poisson errors. We used four explanatory variables: phenotype, sex, season and breeding status.

All results, except for time of commencement to breeding and time interval between consecutive litters (median $\pm \mathrm{SE}$ ), are presented as mean $\pm \mathrm{SD}$. Statistical significance was accepted at $P<0.05$.

\section{Abbreviations}

AC: Antioxidant capacity; BAP: Biological antioxidant potential; BMR: Basal metabolic rate; $m_{b}$ : body mass; OS: Oxidative stress; ROM: Reactive oxygen metabolites

\section{Acknowledgments}

We thank two anonymous reviewers for their constructive comments, which greatly improved our manuscript. Special thanks to Mr. Sławomir Fijałkowski from AVANTI-BIS company (Chodecz, Poland) for donating paper tubes used in the nest-building behavior experiments.

\section{Funding}

This study was supported by the grant \#NCN 2014/13/B/NZ8/04698.

\section{Availability of data and materials}

The datasets used and/or analyzed during the current study are available from the corresponding author on reasonable request.

\section{Authors' contributions}

ASP - acquisition of data, analysis and interpretation of data, drafting the first draft of the manuscript and the revisions, MSW - concept of the study, acquisition of data, critically revising the manuscript. MJ - concept of the study, acquisition of data, critically revising the manuscript. All authors read and approved the final manuscript.

\section{Ethics approval}

All experimental procedures were approved by the Local Committee for Ethics in Animal Research in Bydgoszcz, Poland (decisions nos. 3/2015, $31-$ $33 / 2015,35 / 2015)$

\section{Consent for publication}

Not applicable

\section{Competing interests}

The authors declare that they have no competing interests.

\section{Publisher's Note}

Springer Nature remains neutral with regard to jurisdictional claims in published maps and institutional affiliations.

\section{Author details}

${ }^{1}$ Department of Vertebrate Zoology, Nicolaus Copernicus University, ul. Lwowska 1, 87-100 Toruń, Poland. 'Department of Animal Physiology, Nicolaus Copernicus University, ul. Lwowska 1, 87-100 Toruń, Poland.

Received: 5 February 2019 Accepted: 31 March 2019

Published online: 18 April 2019

References

1. Scholander PF, Hock R, Walters V, Irving L. Adaptation to cold in arctic and tropical mammals and birds in relation to body temperature, insulation, and basal metabolic rate. Biol Bull. 1950;99(2):259-71.

2. McKechnie AE. Phenotypic flexibility in basal metabolic rate and the changing view of avian physiological diversity: a review. J Comp Physiol B. 2008;178(3):235-47.

3. Heldmaier G. Seasonal Acciimatization of energy requirements in mammals: functional significance of body weight control, hypothermia, torpor and hibernation. In: Wieser W, Gnaiger E, editors. Energy transformation in cells and organisms. Stuttgart: Fischer; 1989. p. 130-9.

4. Geiser F. Evolution of daily torpor and hibernation in birds and mammals: importance of body size. Clin Exp Pharmacol Physiol. 1998;25(9):736-9.

5. Ruf T, Geiser F. Daily torpor and hibernation in birds and mammals. Biol Rev. 2015;90(3):891-926.

6. Hoffmann K. The influence of photoperiod and melatonin on testis size, body weight and pelage colour in the Djungarian hamster. J Comp Physiol. 1973:85:267-82.

7. Goldman B, Hall V, Hollister C, Reppert S, Roychoudhury P, Yellon S, et al. Diurnal changes in pineal melatonin content in four rodent species: relationship to photoperiodism. Biol Reprod. 1981;24(4):778-83. 
8. Gorman MR, Zucker I. Seasonal adaptations of Siberian hamsters. II. Pattern of change in day length controls annual testicular and body weight rhythms. Biol Reprod. 1995;53:116-25.

9. Heath HW, Lynch GR. Intraspecific differences for melatonin-induced reproductive regression and the seasonal molt in Peromyscus leucopus. Gen Comp Endocrinol. 1982;48(3):289-95.

10. Nelson RJ. Photoperiod-nonresponsive morphs: a possible variable in microtine population-density fluctuations. Am Nat. 1987;130(3):350-69.

11. Nelson RJ. Photoperiodic regulation of reproductive development in male Praire voles: influence of laboratory breeding. Biol Reprod. 1985;33:418-22.

12. Heideman PD, Rightler M, Sharp K. A potential microevolutionary life-history tradeoff in white-footed mice (Peromyscus leucopus). Funct Ecol. 2005;19(2):331-6.

13. Nelson RJ. Photoperiod influences reproduction in the prairie vole (Microtus ochrogaster). Biol Reprod. 1985;33(3):596-602.

14. Ogilvie $\mathrm{KM}$, Stetson $\mathrm{MH}$. The timing of gonadal refractoriness in the female Turkish hamster (Mesocricetus brandti) is not dependent on the timing of gonadal regression. Biol Reprod. 1990;42:787-91.

15. Whitaker W. Some effects of artificial illumination on the repro-duction in the white-footed mouse, P. Leucopus noveboracensis. J Exp Zool. 1940;83:33-60.

16. Desjardins C, Lopez MJ. Environmental cues evoke differential responses in pituitary-testicular function in deer mice*. Endocrinology. 1983;112(4):1398-406.

17. Nowack J, Stawski C, Geiser F. More functions of torpor and their roles in a changing world. J Comp Physiol B. 2017;187(5-6):889-97.

18. Austad SN, Fischer KE. Mammalian aging, metabolism, and ecology: evidence from the bats and marsupials. J Gerontol. 1991;46(2):B47-53.

19. Geiser F, Turbill C. Hibernation and daily torpor minimize mammalian extinctions. Naturwissenschaften. 2009;96(10):1235-40.

20. Turbill C, Ruf T, Smith S, Bieber C. Seasonal variation in telomere length of a hibernating rodent. Biol Lett. 2013;9(2):20121095.

21. Turbill C, Smith S, Deimel C, Ruf T. Daily torpor is associated with telomere length change over winter in Djungarian hamsters. Biol Lett. 2012;8(2):304-7.

22. Ruf T, Bieber C, Turbill C. Survival, Aging, and Life-History Tactics in Mammalian Hibernators. In: Ruf T, Bieber C, Arnold W, Millesi E, editors. Living in a Seasonal World: Thermoregulatory and Metabolic Adaptations. Berlin, Heidelberg: Springer Berlin Heidelberg; 2012. p. 123-32.

23. Wu CW, Storey KB. Life in the cold: links between mammalian hibernation and longevity. Biomol Concepts. 2016;7(1):41-52.

24. Conti B, Sanchez-Alavez M, Winsky-Sommerer R, Morale MC, Lucero J, Brownell $S$, et al. Transgenic mice with a reduced core body temperature have an increased life span. Science. 2006;314(5800):825-8.

25. Place NJ, Cruickshank J. Graded response to short photoperiod during development and early adulthood in Siberian hamsters and the effects on reproduction as females age. Horm Behav. 2009;55(3):390-7.

26. Place NJ, Tuthill CR, Schoomer EE, Tramontin AD, Zucker I. Short day lengths delay reproductive aging. Biol Reprod. 2004;71(3):987-92.

27. Prendergast BJ, Kriegsfeld LJ, Nelson RJ. Photoperiodic polyphenisms in rodents: neuroendocrine mechanisms, costs, and functions. Q Rev Biol. 2001;76(3):293-325.

28. Lynch GR, Lynch CB, Kliman RM. Genetic analyses of photoresponsiveness in the Djungarian hamster, Phodopus sungorus. J Comp Physiol A. 1989;164(4):475-81.

29. Kliman RM, Lynch GR. Evidence for genetic variation in the occurrence of the photoresponse of the Djungarian hamster, Phodopus sungorus. J Biol Rhythms. 1992;7(2):161-73.

30. Ruf T, Stieglitz A, Steinlechner S, Blank JL, Heldmaier G. Cold exposure and food restriction facilitate physiological responses to short photoperiod in Djungarian hamsters (Phodopus sungorus). J Exp Zool. 1993;267(2):104-12.

31. Freeman DA, Goldman BD. Photoperiod nonresponsive Siberian hamsters: effect of age on the probability of nonresponsiveness. J Biol Rhythm. 1997; 12(2):110-21.

32. Goldman SL, Dhandapani K, Goldman BD. Genetic and environmental influences on short-day responsiveness in Siberian hamsters (Phodopus sungorus). J Biol Rhythm. 2000;15(5):417-28.

33. Barja de Quiroga G. Brown fat thermogenesis and exercise: two examples of physiological oxidative stress? Free Radic Biol Med. 1992;13(4):325-40.

34. Frisard M, Ravussin E. Energy metabolism and oxidative stress: impact on the metabolic syndrome and the aging process. Endocrine. 2006;29(1):27-32.

35. Isaksson C, Sheldon BC, Uller T. The challenges of integrating oxidative stress into life-history biology. BioScience. 2011;61(3):194-202.

36. Speakman JR, Blount JD, Bronikowski AM, Buffenstein R, Isaksson C, Kirkwood TB, et al. Oxidative stress and life histories: unresolved issues and current needs. Ecol Evol. 2015;5(24):5745-57.
37. Latta LC, Tucker KN, Haney RA. The relationship between oxidative stress, reproduction, and survival in a bdelloid rotifer. BMC Ecol. 2019;19(1):7.

38. Garratt M, Vasilaki A, Stockley P, McArdle F, Jackson M, Hurst JL. Is oxidative stress a physiological cost of reproduction? An experimental test in house mice. Proc R Soc Lond B Biol Sci. 2011;278(1708):1098-106.

39. Selman C, Blount JD, Nussey DH, Speakman JR. Oxidative damage, ageing, and life-history evolution: where now? Trends Ecol Evol. 2012;27(10):570-7.

40. Costantini D, Casasole G, Eens M. Does reproduction protect against oxidative stress? J Exp Biol. 2014;217(Pt 23):4237-43.

41. Alonso-Alvarez C, Bertrand S, Devevey G, Prost J, Faivre B, Sorci G. Increased susceptibility to oxidative stress as a proximate cost of reproduction. Ecol Lett. 2004;7(5):363-8.

42. Losdat S, Helfenstein F, Gaude B, Richner H. Reproductive effort transiently reduces antioxidant capacity in a wild bird. Behav Ecol. 2011;22(6):1218-26.

43. Zhao XY, Zhang JY, Cao J, Zhao ZJ. Oxidative Damage Does Not Occur in Striped Hamsters Raising Natural and Experimentally Increased Litter Size. PLoS ONE. 2015:10(10):e0141604.

44. Wiersma P, Selman C, Speakman JR, Verhulst S. Birds sacrifice oxidative protection for reproduction. Proc R Soc Lond B Biol Sci. 2004;271(Suppl 5): 360-3.

45. Monaghan P, Metcalfe NB, Torres R. Oxidative stress as a mediator of life history trade-offs: mechanisms, measurements and interpretation. Ecol Lett. 2009;12(1):75-92.

46. Ołdakowski L, Piotrowska Ż, Chrząścik KM, Sadowska ET, Koteja P, Taylor JR. Is reproduction costly? No increase of oxidative damage in breeding bank voles. J Exp Biol. 2012;215(Pt 11):1799-805.

47. Ołdakowski L, Wasiluk A, Sadowska ET, Koteja P, Taylor JR. Reproduction is not costly in terms of oxidative stress. J Exp Biol. 2015;218(Pt 24):3901-10.

48. Vaanholt LM, Milne A, Zheng Y, Hambly C, Mitchell SE, Valencak TG, et al. Oxidative costs of reproduction: oxidative stress in mice fed standard and low antioxidant diets. Physiol Behav. 2016;154:1-7.

49. Stier A, Reichert S, Massemin S, Bize P, Criscuolo F. Constraint and cost of oxidative stress on reproduction: correlative evidence in laboratory mice and review of the literature. Front Zool. 2012;9(1):37.

50. Bize P, Devevey G, Monaghan P, Doligez B, Christe P. Fecundity and survival in relation to resistance to oxidative stress in a free-living bird. Ecology. 2008;89(9):2584-93.

51. Garratt M, McArdle F, Stockley P, Vasilaki A, Beynon RJ, Jackson MJ, et al. Tissue-dependent changes in oxidative damage with male reproductive effort in house mice. Funct Ecol. 2012;26(2):423-33.

52. Michener GR. Sexual differences in reproductive effort of Richardson's ground squirrels. J Mammal. 1998;79(1):1-19.

53. Timonin ME, Wynne-Edwards KE. Neither reduced photoperiod, nor femalerelated social cues, nor increased maternal thermal stress result in a paternally responsive Phodopus sungorus male. Physiol Behav. 2006;88(4-5):309-16.

54. Wynne-Edwards KE, Lisk RD. Differential effects of paternal presence on pup survival in two species of dwarf hamster (Phodopus sungorus and Phodopus campbelli). Physiol Behav. 1989;45(3):465-9.

55. Turbill C, Bieber C, Ruf T. Hibernation is associated with increased survival and the evolution of slow life histories among mammals. Proc Biol Sci. 2011:278(1723):3355-63

56. Edwards HE, Tweedie CJ, Terranova PF, Lisk RD, Wynne-Edwards KE. Reproductive aging in the Djungarian hamster, Phodopus campbelli. Biol Reprod. 1998;58(3):842-8.

57. Butler MP, Turner KW, Park JH, Schoomer EE, Zucker I, Gorman MR. Seasonal regulation of reproduction: altered role of melatonin under naturalistic conditions in hamsters. Proc R Soc Lond B Biol Sci. 2010;277(1695):2867-74.

58. Boratyński JS, Jefimow M, Wojciechowski MS. Melatonin attenuates phenotypic flexibility of energy metabolism in a photoresponsive mammal, the Siberian hamster. J Exp Biol. 2017;220(Pt 17):3154-61.

59. Healy JE, Burdett KA, Buck CL, Florant GL. Sex differences in torpor patterns during natural hibernation in golden-mantled ground squirrels (Callospermophilus lateralis). J Mammal. 2012;93(3):751-8.

60. Michener GR. Sexual differences in over-winter torpor patterns of Richardson's ground squirrels in natural hibernacula. Oecologia. 1992;89:397-406.

61. Newkirk KD, McMillan HJ, Wynne-Edwards KE. Length of delay to birth of a second litter in dwarf hamsters (Phodopus): evidence for post-implantation embryonic diapause. J Exp Zool. 1997:278(2):106-14.

62. Newkirk KD, Cheung BL, Scribner SJ, Wynne-Edwards KE. Earlier thermoregulation and consequences for pup growth in the Siberian versus Djungarian dwarf hamster (Phodopus). Physiol Behav. 1998;63(3):435-43. 
63. Stulberg SE, Wynne-Edwards KE. Maternal and pup contributions to different patterns of pup growth in Phodopus species. Physiol Behav. 1998; 64(5):715-22.

64. Lim JN, Senior AM, Nakagawa S. Heterogeneity in individual quality and reproductive trade-offs within species. Evolution. 2014;68(8):2306-18.

65. Parker GA, Begon M. Optimal egg size and clutch size - effects of environment and maternal phenotype. Am Nat. 1986;128(4):573-92.

66. Rollinson N, Rowe L. The positive correlation between maternal size and offspring size: fitting pieces of a life-history puzzle. Biol Rev. 2016;91(4): 1134-48.

67. West HE, Capellini I. Male care and life history traits in mammals. Nat Commun. 2016;7:11854.

68. Stockley P, Hobson L. Paternal care and litter size coevolution in mammals. Proc R Soc Lond B Biol Sci. 2016;283(1829):20160140.

69. Przybylo R, Wiggins DA, Merilä J. Breeding success in blue tits: good territories or good parents? J Avian Biol. 2001;32(3):214-8.

70. Wynne-Edwards KE. Biparental care in Djungarian but not Siberian dwarf hamsters (Phodopus). Anim Behav. 1995;50:1571-85.

71. Walton JM, Wynne-Edwards KE. Paternal care reduces maternal hyperthermia in Djungarian hamsters (Phodopus campbelli). Physiol Behav. 1997;63(1):41-7.

72. Jones JS, Wynne-Edwards KE. Paternal hamsters mechanically assist the delivery, consume amniotic fluid and placenta, remove fetal membranes, and provide parental care during the birth process. Horm Behav. 2000;37(2): 116-25.

73. Speakman JR. The physiological costs of reproduction in small mammals. Philos Trans R Soc Lond Ser B Biol Sci. 2008;363(1490):375-98.

74. Bergeron P, Careau V, Humphries MM, Réale D, Speakman JR, Garant D. The energetic and oxidative costs of reproduction in a free-ranging rodent. Funct Ecol. 2011;25(5):1063-71.

75. Sadowska J, Gębczyński AK, Paszko K, Konarzewski M. Milk output and composition in mice divergently selected for basal metabolic rate. J Exp Biol. 2015;218(Pt 2):249-54.

76. Sadowska J, Gębczyński AK, Konarzewski M. Basal metabolic rate is positively correlated with parental investment in laboratory mice. Proc R Soc Lond B Biol Sci. 2013;280(1753):20122576

77. Johnston SL, Souter DM, Erwin SS, Tolkamp BJ, Yearsley JM, Gordon IJ, et al. Associations between basal metabolic rate and reproductive performance in C57BL/6J mice. J Exp Biol. 2007;210(Pt 1):65-74.

78. McLean JA, Speakman JR. Effects of body mass and reproduction on the basal metabolic rate of brown long-eared bats (Plecotus auritus). Physiol Biochem Zool. 2000;73(1):112-21.

79. Oksanen TA, Jonsson P, Koskela E, Mappes T. Optimal allocation of reproductive effort: manipulation of offspring number and size in the bank vole. Proc R Soc Lond B Biol Sci. 2001;268(1467):661-6.

80. Koivula M, Koskela E, Mappes T, Oksanen TA. Cost of reproduction in the wild: manipulation of reproductive effort in the bank vole. Ecology. 2003; 84(2):398-405

81. König B, Markl H. Maternal care in house mice I. The weaning strategy as a means for parental manipulation of offspring quality. Behav Ecol Sociobiol. 1987;20:1-9

82. Flajšman K, Jerina K, Pokorny B. Age-related effects of body mass on fertility and litter size in roe deer. PLoS ONE. 2017;12(4):e0175579.

83. Fuchs S. Optimality of parental investment - the influence of nursing on reproductive success of mother and female young house mice. Behav Ecol Sociobiol. 1982;10(1):39-51.

84. Salmon AB, Marx DB, Harshman LG. A cost of reproduction in Drosophila melanogaster: stress susceptibility. Evolution. 2001:55(8):1600-8.

85. Zhang Y, Brasher AL, Park NR, Taylor HA, Kavazis AN, Hood WR. High activity before breeding improves reproductive performance by enhancing mitochondrial function and biogenesis. J Exp Biol. 2018;221(7):jeb177469.

86. Costantini D. Oxidative stress and hormesis in evolutionary ecology and physiology : a marriage between mechanistic and evolutionary approaches Berlin: Springer; 2014. 348 p p.

87. Kregel KC, Zhang HJ. An integrated view of oxidative stress in aging: basic mechanisms, functional effects, and pathological considerations. Am J Phys Regul Integr Comp Phys. 2007;292(1):R18-36.

88. Sohal RS, Orr WC. The redox stress hypothesis of aging. Free Radic Biol Med. 2012;52(3):539-55.

89. Beckman KB, Ames BN. The free radical theory of aging matures. Physiol Rev. 1998:78(2):547-81
90. Sohal RS, Weindruch R. Oxidative stress, caloric restriction, and aging. Science. 1996;273(5271):59-63.

91. Daan S, Deerenberg C, Dijkstra C. Increased daily work precipitates natural death in the kestrel. J Anim Ecol. 1996:65(5):539-44.

92. Snell TW, King CE. Lifespan and fecundity patterns in rotifers: the cost of reproduction. Evolution. 1977;31(4):882-90.

93. Branco AT, Schilling L, Silkaitis K, Dowling DK, Lemos B. Reproductive activity triggers accelerated male mortality and decreases lifespan: genetic and gene expression determinants in Drosophila. Heredity (Edinb). 2017; 118(3):221-8.

94. Hansen M, Flatt T, Aguilaniu H. Reproduction, fat metabolism, and life span: what is the connection? Cell Metab. 2013;17(1):10-9.

95. Tabatabaie V, Atzmon G, Rajpathak SN, Freeman R, Barzilai N, Crandall J. Exceptional longevity is associated with decreased reproduction. Aging-Us. 2011:3(12):1202-5.

96. Tarin JJ, Gomez-Piquer V, Garcia-Palomares S, Garcia-Perez MA, Cano A. Absence of long-term effects of reproduction on longevity in the mouse model. Reprod Biol Endocrinol. 2014;12:84.

97. Ricklefs RE, Cadena CD. Lifespan is unrelated to investment in reproduction in populations of mammals and birds in captivity. Ecol Lett. 2007;10(10):867-72.

98. Heldmaier G, Steinlechner S, Ruf T, Wiesinger H, Klingenspor M. Photoperiod and thermoregulation in vertebrates: body temperature rhythms and thermogenic acclimation. J Biol Rhythm. 1989;4(2):251-65.

99. Borrás C, Sastre J, García-Sala D, Lloret A, Pallardó FV, Viña J. Mitochondria from females exhibit higher antioxidant gene expression and lower oxidative damage than males. Free Radic Biol Med. 2003:34(5):546-52.

100. Persky AM, Greene P, Stubley L, Howell C, Zaulyanov L, Brazeau GA, Simpkins JW. Protective effect of estrogens against oxidative damage to heart and skeletal muscle in vivo and in vitro. Proc Soc Exp Biol Med. 2008; 232:59-66.

101. Przybylska AS, Wojciechowski MS, Jefimow M. Physiological differences between winter phenotypes of Siberian hamsters do not correlate with their behaviour. Anim Behav. 2019;147:105-14.

102. Puchalski W, Bockler $H$, Heldmaier G. Effect of food deprivtion on thermogenic capacity in the djungarian hamster.pdf; 1983.

103. Gutowski JP, Wojciechowski MS, Jefimow M. Diet affects resting, but not basal metabolic rate of normothermic Siberian hamsters acclimated to winter. Comp Biochem Physiol A Mol Integr Physiol. 2011;160(4):516-23.

104. Lighton JRB, Bartholomew GA, Feener DH. Energetics of locomotion and load carriage and a model of the energy cost of foraging in the leaf-cutting ant Atta colombica Guer. Physiol Zool. 1987;60(5):524-37.

\section{Ready to submit your research? Choose BMC and benefit from:}

- fast, convenient online submission

- thorough peer review by experienced researchers in your field

- rapid publication on acceptance

- support for research data, including large and complex data types

- gold Open Access which fosters wider collaboration and increased citations

- maximum visibility for your research: over $100 \mathrm{M}$ website views per year

At $\mathrm{BMC}$, research is always in progress.

Learn more biomedcentral.com/submissions 